\title{
PENCEMARAN DI SUNGAI BENGAWAN SOLO ANTARA SOLO DAN SRAGEN, JAWA TENGAH
}

\author{
Agus Djoko Utomo'), Mohammad Rasyid Ridho²), \\ Edward Saleh ${ }^{3)}$, dan Dinar Dwi Anugerah Putranto ${ }^{4)}$ \\ 1)Peneliti pada Balai Riset Perikanan Perairan Umum, Mariana-Palembang \\ 2)Dosen pada Fakultas Matematika dan IImu Pengetahuan Alam-Universitas Sriwijaya, Palembang \\ ${ }^{3)}$ Dosen pada Fakultas Pertanian-Universitas Sriwijaya, Palembang \\ ${ }^{4)}$ Dosen pada Fakultas Teknik Sipil-Universitas Sriwijaya, Palembang \\ Teregistrasi I tanggal: 15 Januari 2010; Diterima setelah perbaikan tanggal: 25 Pebruari 2010; \\ Disetujui terbit tanggal: 8 Maret 2010
}

\begin{abstract}
ABSTRAK
Bengawan Solo merupakan sungai yang sudah banyak mengalami perubahan oleh Waduk, Bendungan, Sodetan, dan lain-lain. Bengawan Solo melewati Provinsi Jawa Tengah dan Jawa Timur yang padat penduduk, sekitar 15,2 juta jiwa berdomisili di satuan wilayah Sungai Bengawan Solo dan juga banyak terdapat industri. Permasalahan tersebut dapat berpengaruh langsung terhadap kehidupan organisme air kajian tentang parameter físika-kimia perairan diharapkan dapat memberikan informasi tentang status kualitas perairan di Bengawan Solo. Parameter yang diamati dalam penelitian ini adalah oksigen terlarut, karbondioksida, $\mathrm{pH}$, fenol, minyak-lemak, amonia, $\mathrm{Cd}, \mathrm{Cr}, \mathrm{Zn}, \mathrm{Pb}, \mathrm{Cu}$, dan CN. Terdapat indikasi bahwa Bengawan Solo di daerah Solo-Sragen dan sekitarnya telah tercemar bobot dengan kualitas air buruk yaitu oksigen rendah (beberapa lokasi kurang dari $2 \mathrm{mg} / \mathrm{L}$, karbon dioksida tinggi $(8,8-34,32 \mathrm{mg} / \mathrm{L}), \mathrm{NH}_{3}-\mathrm{N}$ bebas tinggi (beberapa lokasi lebih dari 0,2 $\mathrm{mg} / \mathrm{L}$ ), COD tinggi (1,64-172 mg/L), fenol tinggi (0,087-1,431 mg/L), minyak lemak tinggi $(2,6-54,6 \mathrm{mg} / \mathrm{L})$. Konsentrasi logam bobot pada beberapa lokasi yaitu Kampung Sewu, Bak Kramat, dan Tundungan cukup tinggi yaitu $\mathrm{Cr}=0,180-0,375 \mathrm{mg} / \mathrm{L}, \mathrm{Cu}=0,026-0,293 \mathrm{mg} / \mathrm{L}$, dan $\mathrm{Zn}=0,515-2,892 \mathrm{mg} / \mathrm{L}$. Demikian juga kandungan logam bobot pada ikan sapu-sapu (Liposarcus pardalis) cukup tinggi pada beberapa lokasi Kampung Sewu, Tundungan, Bak Kramat, dan Butuh; $\mathrm{Cr}=0,856-2,154$ mg/kg, Cu=3, 69-198,48 $\mathrm{mg} / \mathrm{kg}, \mathrm{Pb}=1,067-2,006 \mathrm{mg} / \mathrm{kg}$, dan $\mathrm{Zn}=53,516-102,285 \mathrm{mg} / \mathrm{kg}$. Perlu dilakukan pengendalian pencemaran di Bengawan Solo dengan cara meningkatkan kesadaran bersama, pemantauan pembuangan limbah, dan penindakan bagi para pelanggaran.
\end{abstract}

KATAKUNCl: $\quad$ pencemaran, kualitas air, Bengawan Solo

ABSTRACTS: $\quad$ Pollution of Bengawan Solo River between Solo and Sragen, Central Java. By: Agus Djoko Utomo, Mohammad Rasyid Ridho, Edward Saleh, and Dinar Dwi Anugerah Putranto

Bengawan Solo River is highly modified by dams, impoundment, reservoir, channelization, etc. It traverse through Central Java and East Java province in its passage from headwaters to the sea. Industries and heavy population (approximately 15.2 million people) near the river have potentially wreaked havoc upon the river. Study on physical and chemical parameters expected provide enough information on water quality condition in Bengawan Solo River. Parameters under study were disolved oxygen, carbondioxid, $\mathrm{pH}$, fenol, $\mathrm{NH}_{3}-\mathrm{N}$, oil, and grease, $\mathrm{COD}, \mathrm{Cr}, \mathrm{Cd}, \mathrm{Pb}, \mathrm{Zn}, \mathrm{Cu}$, and $\mathrm{CN}$. An overview of water quality of Bengawan Solo River in Solo-Sragen region indicates that the segments is already strongly polluted as indicated as low oxygen (some location less than $2 \mathrm{mg} / \mathrm{L}$ ) and high amount of $\mathrm{CO}_{2}$ (8,8-34.32), high free $\mathrm{NH}_{3}-\mathrm{N}$ (some location more than 0,2 mg/L), $\mathrm{COD}(1,64-172 \mathrm{mg} / \mathrm{L})$, fenol (0.087$1,431 \mathrm{mg} / \mathrm{L})$, and oil and grease $(2,6-54.6 \mathrm{mg} / \mathrm{L})$. Heavy metals content of some location at Kampung Sewu, Bak Kramat, and Butuh were Cr=0,180-0,375 mg/L, Cu=0,026-0,293 mg/L, Zn=0,515-2,892 $\mathrm{mg} / \mathrm{L}$. Heavy metals content in fish tissue of sapu-sapu were high enough at some location (Kampung Sewu, Tundungan, Bak Kramat, and Butuh); $C r=0,856-2,154 \mathrm{mg} / \mathrm{kg}, \mathrm{Cu}=3,69-198,48 \mathrm{mg} / \mathrm{kg}, \mathrm{Pb}=1,067$ 2,006 $\mathrm{mg} / \mathrm{kg}$, and $\mathrm{Zn}=53,516-102,285 \mathrm{mg} / \mathrm{kg}$.

KEYWORDS: $\quad$ pollution, water quality, Bengawan Solo 


\section{PENDAHULUAN}

Bengawan Solo merupakan tipe sungai yang telah banyak mengalami modifikasi dan padat penduduk di sekitarnya. Beberapa tipe modifikasi yang mempengaruhi bentuk keaslian Bengawan Solo antara lain berupa waduk, bendungan, sodetan, dan penimbunan rawa. Beberapa bentuk bendungan besar yang ada di sepanjang Bengawan Solo antara lain di Colo (Sukoharjo), Karang Nongko (Ngawi), Bojonegoro, Babat (Tuban), dan Sembayat (Lamongan). Beberapa waduk yang di aliran daerah Sungai Bengawan Solo antara lain Waduk Gajah Mungkur (Wonogiri), Waduk Botok (Sragen), Waduk Gebyar (Sragen), dan bentuk sodetan (floodway) di Jabung (Tuban).

Bengawan Solo merupakan sungai terpanjang di Pulau Jawa sekitar 600 km, melintasi dua Provinsi yaitu Jawa Tengah dan Jawa Timur dengan luas daerah pengaliran $16.000 \mathrm{~km}^{2}$ (Direktur Jenderal Pengairan Pekerjaan Umum, 1997). Bengawan Solo mempunyai manfaat penting bagi pertanian, perikanan, pariwisata, perkebunan, masyarakat, dan kehidupan organisme air. Waduk dan bendungan lainnya dibangun untuk kepentingan irigasi ke lahan pertanian, penanggulangan banjir, pembangkit tenaga listrik, sumber air minum, perikanan, dan pariwisata. Sebagai contoh Waduk Gajah Mungkur, Wonogiri dapat mengairi sawah seluas 33.200 ha dan pembangkit tenaga listrik $12,4 \mathrm{MW}$ dan dapat mengurangi banjir di daerah Solo-Sragen serta sebagai sumber daya air minum (Universitas Diponegoro, 1992).

Ditinjau dari segi perikanan, Waduk mempunyai arti penting, sebagai contoh di Waduk Gajah Mungkur, Wonogiri pada tahun 2003 produksi ikan pada karamba jaring apung mencapai 882,8 ton (Dinas Kehewanan, Perikanan, dan Kelutan Kabupaten Wonogiri, 2003). Di samping dampak positif, modifikasi badan air juga menimbulkan dampak negatif antara lain penurunan jumlah keragaman jenis atau perubahan jenis organisme air, penurunan volume air di bagian hilir dan sebagainya. Kepadatan penduduk di sepanjang sungai sedikit banyak akan berpengaruh terhadap kondisi lingkungan perairan sungai, sekitar 15,2 juta jiwa tinggal di satuan wilayah Sungai Bengawan Solo. Pembuangan limbah oleh penduduk ke sungai akan menimbulkan pencemaran bahan organik di perairan. Di sekitar Solo telah banyak industri (diperkirakan ada 50 pabrik) antara lain pabrik tekstil, alkohol, penyamakan kulit, mono sodium glutamat (Adjie et al., 2005).
Limbah industri berupa bahan organik maupun anorganik sebaiknya yang dibuang ke sungai diolah lebih dahulu agar tidak mencemari sungai. Ikan hidup dalam media air sehingga perubahan lingkungan perairan akan berdampak langsung terhadap kehidupan ikan. Semakin bertambahnya penggunaan badan air untuk kepentingan irigasi, persawahan, jumlah pemukiman penduduk di sepanjang sungai, serta banyak industri yang membuang limbah ke sungai, maka akan terjadi penurunan kualitas air yang berpengaruh pada kehidupan ikan dan biota air lainnya bahkan manusia.

Penelitian ini bertujuan untuk mendapatkan data tentang kualitas air Bengawan Solo di Sragen, Karang Anyar, Solo, dan sekitarnya. Diharapkan penelitian ini dapat memberikan informasi tentang status kualitas perairan di Bengawan Solo dan dapat memberikan masukan atau saran untuk pengelolaan sumber daya perairan dan perikanan di Bengawan Solo.

\section{BAHAN DAN METODE}

Penelitian ini dilakukan antara bulan Mei sampai Desember 2005, dengan survei ke lapangan pada bulan Mei, Agustus, September, Oktober, dan Desember. Parameter lingkungan air yang diamati dapat dilihat pada Tabel 1. Stasiun pengambilan contoh air meliputi Kampung Sewu (Solo), Juruk (Solo), Bak Kramat (Karang Anyar), Tundungan (Karang Anyar), Butuh (Sragen), Tenggak (Sragen), dan Cemeng (Sragen) dapat dilihat pada Gambar 1. Pengambilan contoh air juga dilakukan oleh observer pada saat ada ikan mabuk karena diduga adanya pencemaran. Apabila pada suatu saat ikan banyak yang mabuk maka observer mengambil contoh air kemudian dimasukan ke dalam botol dan dicatat lokasi serta tanggal pengamatan.

Untuk mengetahui kandungan logam berat yang terdapat pada daging ikan, maka dilakukan analisis daging ikan. Jenis ikan yang dipilih adalah ikan yang selalu berada di lokasi tersebut yaitu ikan sapu-sapu. Parameter logam berat dalam daging ikan yang diamati yaitu $\mathrm{Cr}, \mathrm{Cu}, \mathrm{Pb}, \mathrm{Zn}$, dan $\mathrm{Cd}$.

Contoh dari lapangan selanjutnya diperiksa di Laboratorium, metode analisis laboratorium mengacu pada APHA, 1986. Selanjutnya data dari laboratorium dianalisis dengan metode deskriptif berupa tabulasi data. 
Pencemaran di Sungai Bengawan Solo antara Solo dan Sragen, Jawa Tengah (Utomo, A.D., et al.)

Tabel 1. Parameter dan metode analisis contoh air

Table 1. Parameters and methods of water sample analys

\begin{tabular}{|c|c|c|}
\hline Parameter & Satuan & Metode dan peralatan \\
\hline 1. Suhu & ${ }^{\circ} \mathrm{C}$ & Insitu, Temometer. \\
\hline 2. Kecerahan & $\mathrm{cm}$ & Insitu, Pining sechi. \\
\hline 3. Counductivity & $\mu \mathrm{S} / \mathrm{cm}$ & Insitu, Counductivity meter. \\
\hline 3. $\mathrm{pH}$ & $\mathrm{pH}$ unit & Insitu, pH universal indicator. \\
\hline 4. Karbondioksida & $\mathrm{mg} / \mathrm{L}$ & Insitu, mefode tìnimetri dengan $\mathrm{NaOH}$ sebagai titrant. \\
\hline 5. Oksigen terlarut & $\mathrm{mg} / \mathrm{L}$ & Insitu, DO mefer. \\
\hline 6. Alkalinitas & $\mathrm{mg} / \mathrm{L}$ & Insitu, metode titrimetri dengan larutam $\mathrm{H}_{2} \mathrm{SO}_{4}$ sebagai titrant. \\
\hline 7. BOD-s & $\mathrm{mg} / \mathrm{L}$ & Insitu, botol gelap-terang inkubasi 5 hari. Metode titrimetri dengan larutan thiosulfat sebagai titrant. \\
\hline 8. $\mathrm{PO}_{4}-\mathrm{P}$ & $\mathrm{mg} / \mathrm{L}$ & Metode Vanadate molibdate, Spectro-photometric. \\
\hline 9. $\mathrm{NO}_{2}-\mathrm{N}$ & $\mathrm{mg} / \mathrm{L}$ & Metode Nessler, Spectrophoto metric. \\
\hline 10. $\mathrm{NO}_{2}-\mathrm{N}$ & $\mathrm{mg} / \mathrm{L}$ & Mefode Nessler, Spectrophoto metric. \\
\hline 11. COD & $\mathrm{mg} / \mathrm{L}$ & Mefode Dichromate Reflux, titrimetri dengan standard ferrous ammonium sulfat sebagai titrant. \\
\hline 12. $\mathrm{N}-\mathrm{NH}_{2}$ (total) & $\mathrm{mg} / \mathrm{L}$ & Metode Phenate. Spectrophoto metric. \\
\hline 13. $\mathrm{N}-\mathrm{NH}_{2}$ (bebas) & $\mathrm{mg} / \mathrm{l}$ & Persentase terhadap ammonia total berdasarkan pada suhu dan pH (Lampiran 1). \\
\hline 14. Fenol & $\mathrm{mg} / \mathrm{L}$ & Metode extrasi khioroform, Spectro photometric. \\
\hline 15. Minyak lemak & $\mathrm{mg} / \mathrm{L}$ & Mefode partition-gravimetric, extrasi petroleum, Spectrophotometric. \\
\hline 16. H2S & $\mathrm{mg} / \mathrm{L}$ & Metode methylene blue, Spectrophoto metric. \\
\hline 17. TDS & $\mathrm{mg} / \mathrm{L}$ & TDS mefer. \\
\hline 18. TSS & $\mathrm{mg} / \mathrm{L}$ & Metode gravimetric pengeningan $105^{\circ} \mathrm{C}$. \\
\hline 19. $\mathrm{Cr}$ & $\mathrm{mg} / \mathrm{L}$ & Chromatrographic, Spectrophotometric. \\
\hline 20. Cd & $\mathrm{mg} / \mathrm{L}$ & Atomic absorbtion, Spectrophotometric. \\
\hline 21. $\mathrm{Pb}$ & $\mathrm{mg} / \mathrm{L}$ & Dithizone, Spectrophotometric. \\
\hline $22 . \mathrm{Zn}$ & $\mathrm{mg} / \mathrm{L}$ & Zincon, Spectrophotometric. \\
\hline 23. $\mathrm{Cu}$ & $\mathrm{mg} / \mathrm{L}$ & Bathocuproine, Spectrophotometric. \\
\hline 24. $\mathrm{CN}$ & $\mathrm{mg} / \mathrm{L}$ & Mass Spectrophotometric. \\
\hline
\end{tabular}

Sumber/Sources: APHA (1981)

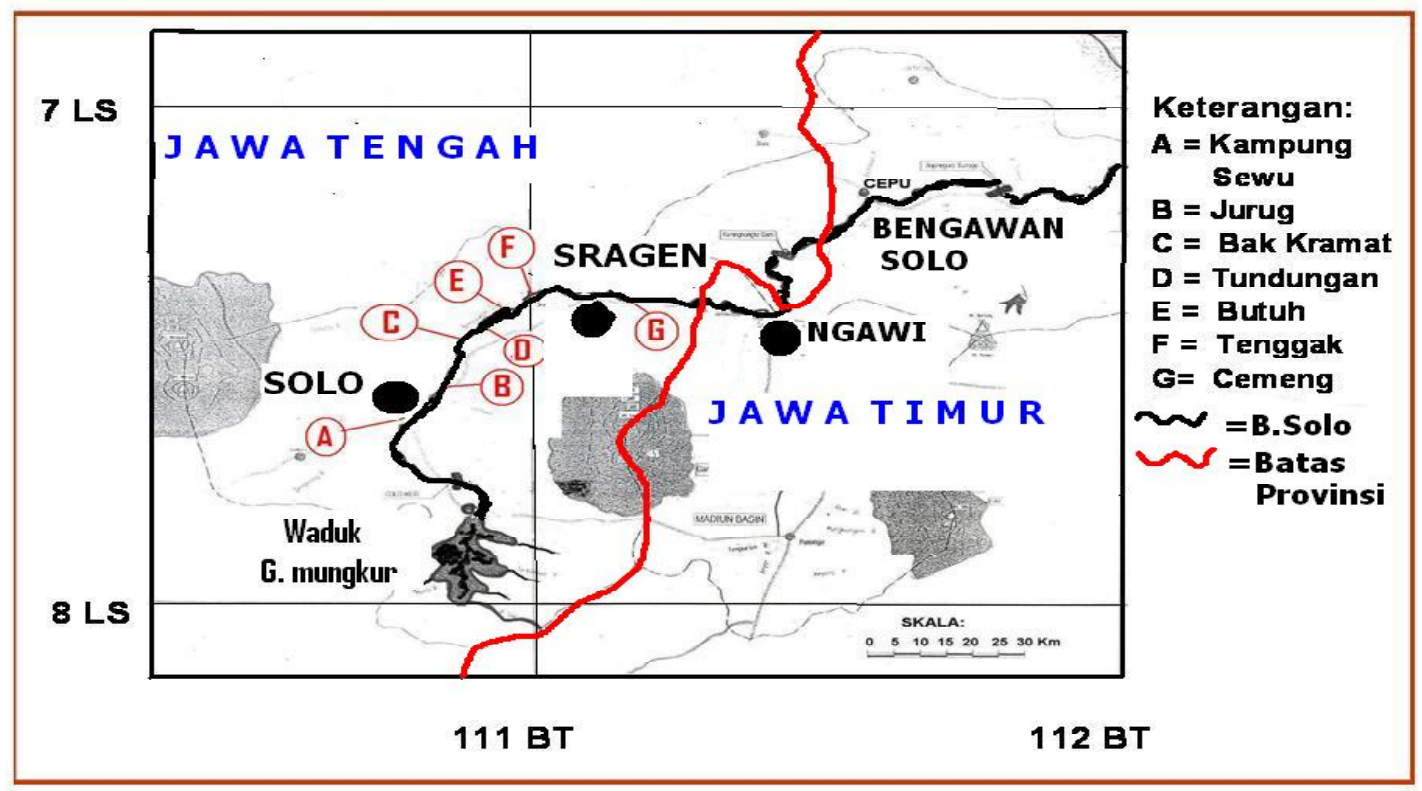

Gambar 1. Peta lokasi penelitian di Bengawan Solo.

Figure 1. Map showing research location at Solo River. 


\section{HASIL DAN BAHASAN}

\section{Pencemaran Non Logam}

Perairan Bengawan Solo terutama di Solo, Karang Anyar, dan Sragen menunjukan indikasi telah tercemar yang cukup serius (Tabel 2). Nilai COD di Desa Cemeng (Kabupaten Sragen) mencapai 127,5 $\mathrm{mg} / \mathrm{L}$, menunjukan perairan tersebut sudah tercemar karena sudah melebihi nilai $20 \mathrm{mg} / \mathrm{L}$ yang merupakan batas nilai untuk perairan tidak tercemar (UNESCO/ WHO/UNEP yang dikutip oleh Effendie 2000). Nilai COD yang tinggi menggambarkan banyak pencemaran kimiawi anorganik dan organik yang dapat menurunkan kandungan oksigen di perairan sehingga akan mengganggu pernapasan organisme air.

Nilai oksigen terlarut di Desa Tenggak dan Butuh (Kabupaten Sragen) terendah 1,94 mg/L, Tundungan (Kabupaten Karang Anyar) terendah=1,93 mg/L, bahkan di Desa Cemeng (Kabupaten Sragen) dan Bak Kramat (Kabupaten Karang Anyar) pernah tercatat mencapai $0 \mathrm{mg} / \mathrm{L}$. Kandungan oksigen di perairan yang baik untuk organisme air sebaiknya lebih $4 \mathrm{mg} /$ $\mathrm{L}$, sedangkan oksigen terlarut kurang dari $2 \mathrm{mg} / \mathrm{L}$ dapat menyebabkan kematian beberapa jenis ikan. Kandungan oksigen yang rendah di suatu perairan dapat disebabkan karena reduksi oksigen oleh bahan pencemar yang masuk ke perairan. Menurut informasi dari masyarakat setempat (Utomo, et al., 2006) di perairan Desa Tenggak dan Desa Cemeng dalam satu bulan terjadi 3-4 kali pencemaran yang serius, yang menyebabkan airnya sangat berbau (sengak) dan ikan banyak yang mengapung (mabuk). Kejadian ini oleh masyarakat setempat diberi istilah Pladu.

Nilai karbondioksida tertinggi di Jurug (Solo), Desa Tenggak, Cemeng, Kampung Sewu, Tundungan, Bak Kramat, dan Butuh yaitu masing-masing 14,44; 12,32; 34,$32 ; 13,2 ; 15,84 ; 24,64$; dan $12,32 \mathrm{mg} / \mathrm{L}$. Karbondioksida $\left(\mathrm{CO}_{2}\right)$ yang tinggi di perairan bersifat racun bagi ikan karena dapat mengganggu pernapasan. Kandungan karbondioksida yang tinggi dapat disebabkan karena hasil dekomposisi bahan pencemaran di perairan. Untuk kepentingan perikanan konsentrasi karbondioksida sebaiknya kurang dari 5 $\mathrm{mg} / \mathrm{L}$, konsentrasi karbondioksida $10 \mathrm{mg} / \mathrm{L}$ dapat ditolerir oleh organisme akuatik untuk tumbuh namun kadar oksigen terlarut cukup (Boyd, 1988 dalam Effendie, 2000).

Kandungan fenol tertinggi di Desa Tenggak (Sragen), Cemeng (Sragen), Kampung Serwu (Solo), Tundungan (Karang Anyar), dan Bak Kramat (Karang Anyar) masing-masing 1,$431 ; 0,259 ; 0,184 ; 0,082$; dan 0,483 mg/L. Bila tidak ada pencemaran, kadar fenol di perairan alami sangat kecil dan sumber fenol berasal dari hasil limbah industri. Kadar fenol lebih dari $0,01 \mathrm{mg} / \mathrm{L}$ bersifat toksik bagi ikan dan mengakibatkan perubahan sifat organoleptik air (UNESCO/WHO/UNEP dalam Effendie, 2000).

Kandungan minyak lemak pada beberapa stasiun pengamatan cukup tinggi seperti di Juruk (Solo) $=8,6$ $\mathrm{mg} / \mathrm{L}$, Kampung Sewu (Solo)=4,6 mg/L, Tundungan (Karang Anyar) $=2,6 \mathrm{mg} / \mathrm{L}$, Bak Kramat (Karang Anyar) $=5,8 \mathrm{mg} / \mathrm{L}$, Tenggak (Sragen) $=8,7-54,6 \mathrm{mg} / \mathrm{L}$, dan Cemeng (Sragen) $=25,6 \mathrm{mg} / \mathrm{L}$. Keberadaan minyak lemak di perairan berasal dari limbah domestik ataupun industri, kadar minyak lemak lebih dari $0,3 \mathrm{mg} / \mathrm{L}$ bersifat toksik bagi beberapa jenis ikan air tawar (UNESCO/WHO/UNEP dalam Effendie, 2000).

Kandungan amonia bebas $\left(\mathrm{N}-\mathrm{NH}_{3}\right)$ pernah tercatat cukup tinggi pada beberapa stasiun yaitu di Juruk $=0,312 \mathrm{mg} / \mathrm{L}$, Butuh=0,103 $\mathrm{mg} / \mathrm{L}$, Tenggak $=1,057 \mathrm{mg} / \mathrm{L}$, dan Cemeng $=0,927 \mathrm{mg} / \mathrm{L}$. Kadar amonia di perairan dapat berasal dari proses dekomposisi bahan pencemaran organik. Kandungan amonia yang tinggi di perairan merupakan indikasi adanya pencemaran bahan organik di perairan, kadar amonia bebas melebihi $0,2 \mathrm{mg} / \mathrm{L}$ dapat menyebabkan kematian beberapa jenis ikan (Sawyer \& McCarty dalam Effendie, 2000).

Kadar nitrit $\left(\mathrm{N}-\mathrm{NO}_{2}\right)$ hampir di seluruh stasiun pengamatan telah melebihi angka yang sudah ditetapkan. Nilai tertinggi pada stasiun pengamatan Kampung Sewu, Tundungan, Bak Kramat, Butuh, Jurug, Tenggak, Cemeng, masing-masing yaitu 1,006; 0,$111 ; 0,339 ; 0,310 ; 2,006 ; 0,06$; dan 0,101 mg/L. Kadar nitrit di perairan alami sekitar $0,001 \mathrm{mg} / \mathrm{L}$ dan sebaiknya tidak melebihi $0,06 \mathrm{mg} / \mathrm{L}$, nitrit bersifat racun bagi ikan. (Canadian Council of Resorce and Environment Ministers dalam Effendie, 2000). Sumber nitrit dapat berupa limbah industri dan limbah domestik.

\section{Pencemaran Logam Berat di Perairan}

Logam berat dalam perairan tidak mengalami regulasi oleh organisme air, sehinggga terus terakumulasi dalam tubuh. Pada umumnya makin tinggi kandungan logam berat di perairan akan berpengaruh terhadap jumlah logam berat yang terakumulasi dalam tubuh organisme air. Logam berat dalam tubuh manusia dapat lewat makanan, minuman, dan udara yang dihirup. Logam berat bersifat akumulatif dalam rantai makanan, konsentrasi akan meningkat pada tingkat trofik level yang lebih tinggi, 
maka seperti ikan dan manusia pemakan ikan sangat berpotensi terakumulasi logam berat dari percemaran di perairan.

Kandungan logam berat dapat dilihat dibeberapa stasiun cukup tinggi. Kadar kromium ( $\mathrm{Cr}$ ) telah melebihi ambang batas di Kampung Sewu $=0,375 \mathrm{mg} /$ L; Bak Kramat 0,180-0,226 mg/L; Tundungan $=0,233$ $\mathrm{mg} / \mathrm{L}$. Kromium termasuk unsur yang jarang ditemukan pada perairan alami (Effendie, 2000). Kromium di perairan pada umumnya berasal dari limbah industri logam, tekstil, kertas, penyamaan kulit, treatment wool, dan lain-lain. Kadar kromium yang aman bagi kehidupan akuatik adalah $0,05 \mathrm{mg} / \mathrm{L}$ (Moore dalam Effendie, 2000 dan Peraturan Pemerintah No.82 Tahun 2001 dalam Dewi et al., 2006). Garam-garam kromium yang masuk ke dalam tubuh manusia dengan jumlah cukup besar akan mengakibatkan kerusakan pada sistem pencernaan (Effendie, 2000).
Kadar tembaga $(\mathrm{Cu})$ telah melebihi ambang batas yaitu di Kampung Sewu=0,026 mg/L, Kebak Kramat $=0,034-0,293 \mathrm{mg} / \mathrm{L}$, dan Tundungan $=0,050 \mathrm{mg} /$ L. Peraturan Pemerintah No.82 Tahun 2001 dalam Dewi et al., 2006 menetapkan kadar tembaga di perairan maksimum $0,02 \mathrm{mg} / \mathrm{L}$. Pada perairan alami kadar tembaga lebih kecil 0,02 mg/L (Moore dalam Effendie, 2000). Limbah industri kawat, pelapis logam, pipa, dan lain-lain. Konsumsi air yang mengandung tembaga yang tinggi dapat mengakibatkan kram perut, mual, gangguan fungsi ginjal, dan hati. Kadar zinc $(\mathrm{Zn})$ di perairan Kampung Sewu=1,332 mg/L, Kebak Kramat=0,968-2,892 $\mathrm{mg} / \mathrm{L}$, dan Tundungan $=0,515 \mathrm{mg} / \mathrm{L}$. Kadar Zn pada perairan alami sekitar kurang dari 0,05 mg/L (Moore dalam Effendie, 2000). Kadar Zn di perairan menurut Peraturan Pemerintah No.82 Tahun 2001 dalam Dewi et al., 2006 maksimum $0,05 \mathrm{mg} / \mathrm{L}$. Zn digunakan pada industri besi baja, cat, karet, tekstil, kertas, dan bubur kertas (Eckenfelder dalam Effendie, 2000).

Tabel 2.

Table 2.

Fisika-kimia perairan Bengawan Solo di Daerah Solo, Karang Anyar, Sragen Physical and chemical parameters of Bengawan Solo River in Solo, Karang Anyar, Sragen Region

\begin{tabular}{|c|c|c|c|c|c|c|c|c|}
\hline No. & Parameter & $\begin{array}{l}\text { Kampung } \\
\text { Sewu (Solo) }\end{array}$ & $\begin{array}{l}\text { Jurug } \\
\text { (Solo) }\end{array}$ & $\begin{array}{l}\text { Bak Kramat } \\
\text { (Kr. Anyar) }\end{array}$ & $\begin{array}{l}\text { Tundungan } \\
\text { (Kr. Anyar) }\end{array}$ & $\begin{array}{l}\text { Butuh } \\
\text { (Sragen) }\end{array}$ & $\begin{array}{l}\text { Tenggak } \\
\text { (Sragen) }\end{array}$ & $\begin{array}{l}\text { Cemeng } \\
\text { (Sragen) }\end{array}$ \\
\hline 1. & Posisi (GPS) & $\begin{array}{l}S=110.54 .10 \\
E=07.45 .06\end{array}$ & $\begin{array}{l}S=7^{*} 34^{\prime} \\
E=110^{\circ} 51^{\prime \prime}\end{array}$ & $\begin{array}{l}S=110.53 .02 \\
E=07.20 .38\end{array}$ & $\begin{array}{l}S=110.52 .33 \\
E=07.32 .10\end{array}$ & $\begin{array}{l}E=111.08 .93 \\
S=07.20 .38\end{array}$ & $\begin{array}{l}S=7^{\circ} 23^{\prime \prime} \\
E=110^{\circ} 57^{\prime}\end{array}$ & $\begin{array}{l}S=7^{\circ} 20^{\prime} \\
E=111^{\circ} 4^{\prime \prime}\end{array}$ \\
\hline 2. & Ketinggian tempat (m) & 103 & 137 & 95 & 92 & 78 & 109 & 109 \\
\hline 3. & Suhu ("C) & $27-39$ & $27-29$ & $27-30$ & $27-29$ & $28-29$ & $25-29$ & $25-29$ \\
\hline 4. & Kecerahan $(\mathrm{cm})$ & & & $10-15$ & $15-25$ & $10-40$ & & \\
\hline 5. & Oksigen (mg/L) & $2,47-7,20$ & $5,5-7,09$ & $0-4,0$ & $1.93-10.58$ & $1,94-4,77$ & $1,94-9,41$ & $0-9.54$ \\
\hline 6. & $\mathrm{CO}_{2}$ & $12,32-13,2$ & $3,52-14,44$ & $17,6-24,64$ & $8,8-15,84$ & $10,56-12,32$ & $9,33-12,32$ & $12,32-34,32$ \\
\hline 7. & $\mathrm{pH}$ & $7-7,5$ & $7,0-8$ & 7,5 & $7,5-8,0$ & $7-7,5$ & $7,0-8$ & $7,5-8$ \\
\hline 8. & $\mathrm{DHL}(\mu \mathrm{S} / \mathrm{cm})$ & $342-432$ & $375-540$ & $377-575$ & $315-453$ & $337-433$ & $470-528$ & $422-575$ \\
\hline 9. & $\mathrm{P}_{-} \mathrm{PO}_{4}(\mathrm{mg} / \mathrm{L})$ & - & 0,079 & - & & & $0,11-2,12$ & $0,183-6,96$ \\
\hline 10. & $\mathrm{~N}-\mathrm{NO}_{2}(\mathrm{mg} / \mathrm{L})$ & $0,096-1,006$ & 2,195 & 0,91 & $0,055-1,35$ & $0,029-1,477$ & 2,8 & 8,8 \\
\hline 11. & $\mathrm{BOD}(\mathrm{mg} / \mathrm{L})$ & $1,38-1,41$ & $1,55-4,39$ & 0,23 & - & 2,02 & $1,42-8,38$ & $3,36-8,36$ \\
\hline 12. & $\mathrm{COD}(\mathrm{mg} / \mathrm{L})$ & 1,644 & 1,656 & 8,32 & 5,491 & 1,83 & $16,56-150,9$ & 127,512 \\
\hline 13. & Fenol (mg/L) & 0,1842 & - & 0,4835 & 0,0816 & - & $0,238-1,431$ & 0,259 \\
\hline 14. & Minyak lemak (mg/L) & 4,6 & 8,6 & 5,6 & 2,6 & - & $8,7-54,6$ & 25,6 \\
\hline 15. & $\mathrm{~N}-\mathrm{NO}_{2}(\mathrm{mg} / \mathrm{L})$ & $0,096-1,006$ & $0,033-2,006$ & $0,328-0,339$ & 0.111 & $0,161-0,310$ & $0,003-0,06$ & $0,003-0,101$ \\
\hline 16. & $\mathrm{~N}-\mathrm{NH}_{2}(\mathrm{mg} / \mathrm{L})$ (total) & $0,250-1,440$ & $0,116-6,399$ & $1,399-1,95$ & 0,287 & $0,25-2,15$ & $0,15-21,67$ & $0,1-19,05$ \\
\hline 17. & $\mathrm{~N}-\mathrm{NH}_{2}$ (mg/L) (bebas) & $0,005-0,023$ & $0,006-0,312$ & $0,069 \cdot 0,093$ & 0,014 & $0,012-0,103$ & $0,007-1,057$ & $0,005-0,927$ \\
\hline 18. & $\mathrm{H} 2 \mathrm{~S}(\mathrm{mg} / \mathrm{L})$ & 0,094 & - & 0,283 & 0,094 & 0 & - & - \\
\hline 19. & $\mathrm{TDS}$ (mg/L) & $0,10-190$ & - & $0,24-240$ & $0,05-178$ & $0,34-188$ & - & - \\
\hline 20. & $\mathrm{TSS}(\mathrm{mg} / \mathrm{L})$ & $0,08-135$ & - & $0,10-4,0$ & 80 & $0,1-188$ & - & - \\
\hline 21. & $\mathrm{Cr}(\mathrm{mg} / \mathrm{L})$ & 0,375 & - & $0,180-0,226$ & 0,233 & - & - & - \\
\hline 22 & $\mathrm{Cu}(\mathrm{mg} / \mathrm{L})$ & 0,026 & - & $0,034-0,293$ & 0,050 & - & - & - \\
\hline 23. & $\mathrm{~Pb}(\mathrm{mg} / \mathrm{l})$ & $\pi$ & - & $\pi$ & $\pi$ & - & - & - \\
\hline 24. & $\mathrm{Zn}(\mathrm{mg} / \mathrm{l})$ & 1,332 & - & $0,968-2,892$ & 0,515 & - & - & - \\
\hline 26. & $\mathrm{Cd}(\mathrm{mg} / \mathrm{l})$ & $\pi$ & - & $\pi$ & $\pi$ & - & - & - \\
\hline 27. & $\mathrm{CN}(\mathrm{mg} / \mathrm{l})$ & $\pi$ & - & $0,001-0,08$ & $\pi$ & - & - & - \\
\hline
\end{tabular}

Keterangan/Remarks: (-) tidak tercatat; (TT) tidak terdekteksi 


\section{Kandungan Logam Berat dalam Ikan}

Kandungan logam berat dalam tubuh ikan sapusapu cukup tinggi (Tabel 3 ). Kandungan logam berat di dalam makanan tak mengenal ambang batas, karena bersifat akumulatif, walaupun sedikit tetapi bila sering dimakan akhirnya juga banyak (Rozanah, 2004).

Kadar Cu pada ikan sapu-sapu di stasiun pengamatan Kebak Kramat dan Butuh masing-masing 3,69-198,48 mg/kg, ambang batas Cu dalam bahan makan yaitu 20 mg/kg (Direktur Jenderal POM, 1989 dalam Dewi et al., 2006). Dalam jumlah kecil Cu (1 $\mathrm{mg} /$ hari) diperlukan tubuh untuk pembentuk $\mathrm{Hb}$, kolagen, pembuluh darah, dan myelin otak. Mengkonsumsi daging ikan yang mengandung tembaga yang tinggi dapat mengakibatkan kerusakan syaraf, otak fungsi ginjal, kerusakan kornea mata, dan hati.

Kadar Zn pada ikan sapu-sapu di Kampung Sewu, Tundungan, Bak Kramat, Butuh berkisar antara 53,516-102,285 mg/kg. Ambang batas kadar Zn dalam makanan yaitu $100 \mathrm{mg} / \mathrm{kg}$ (Direktur Jenderal POM, 1989 dalam Dewi et al., 2006). Unsur Zn sebetulnya diperlukan untuk kesehatan tubuh namun dalam konsentrasi besar merupakan racun, dapat menggantikan tempat mineral lain yang dibutuhkan tubuh, sehingga dapat mengganggu sistem peredaran darah, anemia, kepala pusing, dan sebagainya.

Kandungan $\mathrm{Cr}$ pada ikan sapu-sapu di Bak Kramat dan Butuh antara 0,856-2,154 mg/kg, ambang batas $\mathrm{Cr}$ dalam bahan makanan $2,5 \mathrm{mg} / \mathrm{kg}$. (Direktur Jenderal POM, 1989 dalam Dewi et al., 2006). Dampak dari kelebihan $\mathrm{Cr}$ dalam tubuh dapat mengakibatkan kerusakan fungsi peredaran darah, gangguan fungsi ginjal dan hati, dan imunitas menurun. Dalam dosis kecil diperlukan tubuh untuk membantu metabolisme glukosa, lemak, dan kolesterol agar normal.

Kandungan $\mathrm{Pb}$ pada ikan sapu-sapu di Bak Kramat dan Butuh 2,004-2,006 mg/kg, ambang batas
$\mathrm{Pb}$ dalam bahan makanan yaitu $2 \mathrm{mg} / \mathrm{kg}$. (Direktur Jenderal POM, 1989 dalam Dewi et al., 2006). Tandatanda pertama keracunan $\mathrm{Pb}$ yaitu sulit konsentrasi,depresi, dan sakit kepala. Apabila sudah akut dapat menyebabkan gangguan fungsi syaraf, ginjal, hati, anemia, kejang-kejang, epilepsi, dan gangguan reproduksi pada ibu yang hamil.

Pusat Penelitian Universitas Sebelas Maret (2004) mengindikasikan Bengawan Solo telah tercemar Cd dan $\mathrm{Cr}$ dengan kadar Cr sudah mencapai $3,8-7,5 \mathrm{mg} /$ $\mathrm{kg} /$ padi, padahal ambang batasnya hanya $2,5 \mathrm{mg} /$ $\mathrm{kg}$. Pencemaran tersebut telah menjadi bagian dari sistem produksi komoditi pertanian seperti padi, palawija, dan air untuk kebutuhan rumah tangga.

Utomo et al. (2006) mengatakan bahwa jenis ikan di Bengawan Solo sekitar Solo-Sragen didominansi ikan sapu-sapu. Ikan asli lainnya seperti ikan bader (Barbodes gonionotus), tagih (Mystus nemurus), wader (Rasbora spp.), lele (Clarias spp.), dan kutuk (Channa striata) sekarang sudah sulit didapatkan. Hanya ikan sapu-sapu yang tahan terhadap kondisi air yang telah tercemar, ikan tersebut sekarang sudah mulai dikonsumsi oleh masyarakat terutama di daerah Cemeng-Sragen. Pada saat musim penghujan kadang-kadang ada ikan (pada umumnya ikan bader) dari hulu sungai (Wonogiri) hanyut bersama arus ke hilir, sesampainya di daerah Solo-Sragen ikan tersebut mabuk karena melewati perairan yang tercemar.

Ikan sapu-sapu di Bengawan Solo telah tercemar logam berat jenis $\mathrm{Cd}$ dan $\mathrm{Pb}$ (Universitas Muhamadiyah Surakarta, 2004). Hasil pemantauan Direktur Jenderal Pengairan Pekerjaan Umum (1997) yang dilakukan pada bulan April sampai Mei 2005 menunjukan pencemaran dibeberapa titik telah melampaui ambang batas, baik berdasarkan pada klasifikasi kelas I maupun II yang terdiri atas klorin bebas, deterjen, phospat, minyak-lemak, COD, BOD, $\mathrm{DO}$, besi, krom, dan tembaga. Pemantauan tersebut dilakukan pada Sungai Bengawan Solo dan kali Madiun pada 10 titik terutama pada ruas Jurug-Cepu.

Tabel 3. Kandungan logam berat pada ikan sapu-sapu

Table 3. Heavy metal contained of Liposarcus pardalis

\begin{tabular}{cccccc}
\hline \multirow{2}{*}{ No. } & \multirow{2}{*}{ Parameter/Parameter } & \multicolumn{4}{c}{ Lokasi/Location } \\
\cline { 3 - 6 } & & Kampung Sewu & Tundungan & Kebak Kramat & Butuh \\
\hline 1. & $\mathrm{Cr}(\mathrm{mg} / \mathrm{kg})$ & $\mathrm{tt}$ & $\mathrm{tt}$ & 0,856 & 2,154 \\
2. & $\mathrm{Cu}(\mathrm{mg} / \mathrm{kg})$ & 17,86 & 3,69 & 51,33 & 198,48 \\
3. & $\mathrm{~Pb}(\mathrm{mg} / \mathrm{kg})$ & 1,067 & 1,811 & 2,006 & 2,004 \\
4. & $\mathrm{Zn}(\mathrm{mg} / \mathrm{gr})$ & 53,516 & 47,884 & 102.285 & 83,333 \\
5. & $\mathrm{Cd}(\mathrm{mg} / \mathrm{gr})$ & $\mathrm{tt}$ & $\mathrm{tt}$ & $\mathrm{tt}$ & $\mathrm{tt}$ \\
\hline
\end{tabular}

Keterangan/Remarks: $\mathrm{tt}=$ tak terdeteksi 


\section{KESIMPULAN}

1. Perairan antara Solo-Sragen dan sekitarnya telah tercemar dengan indikasi oksigen rendah, karbondioksida tinggi, COD tinggi, fenol tinggi, minyak lemak tinggi.

2. Kandungan logam berat seperti $\mathrm{Cr}, \mathrm{Cu}$, dan $\mathrm{Zn}$ pada perairan di beberapa lokasi sudah melebihi ambang batas, hal yang sama juga ditemui pada kandungan logam berat $\mathrm{Cr}, \mathrm{Cu}, \mathrm{Pb}$, dan $\mathrm{Zn}$ pada ikan sapu-sapu.

\section{SARAN}

Agar dilakukan pengendalian pencemaran di Bengawan Solo dengan cara meningkatkan kesadaran bersama, pemantauan pembuangan limbah, dan penindakan bagi pelaku pelanggaran.

\section{PERSANTUNAN}

Tulisan ini merupakan kontribusi dari kegiatan hasil riset keragaman jenis ikan dan pemanfaatan sumber daya perikanan di Bengawan Solo, T. A. 2005, di Balai Riset Perikanan Perairan Umum-Mariana, Palembang.

\section{DAFTAR PUSTAKA}

APHA. 1981. Standard Methods for the Examinations of Water and Wastewater. Washington D. C.

Adjie, S., A. D., Utomo, \& N. Muflikah. 2005. Kajian pencemaran dan biologi ikan Jambal di Bengawan Solo. Laporan Teknis Balai Riset Perikanan Perairan Umum. Palembang.

Dewi, J., Hendrianto, Kurniastuti, \& M. Brite. 2006. Prosiding Seminar Nasional Tahunan III Hasil Penelitian Perikanan dan Kelautan. Bidang Ekologi dan Toksikologi. www.semnaskan_ugm_2006. Tanggal 13 Juli 2007.
Dinas Kehewanan, Perikanan, dan Kelautan Kabupaten Wonogiri. 2003. Pengelolaan Usaha Perikanan di Waduk Gajah Mungkur Kabupaten Wonogiri.

Direktur Jenderal Pengairan Pekerjaan Umum. 1997. Rencana Pengelolaan Lingkungan, Rencana Pemantauan Lingkungan pada AMDAL Perbaikan, dan Pengaturan Sungai Bengawan Solo bagian Hilir. Direktur Jenderal Pengairan. Departemen Pekerjaan Umum. Proyek Induk Pengembangan Wilayah Bengawan Solo.

Effendie, H. 2000. Telaah Kualitas Air bagi Pengelolaan Sumber Daya dan Lingkungan Perairan. Buku Materi Kuliah pada Jurusan Manajemen Sumber Daya Perikanan. Fakultas Perikanan dan IImu Kelautan. Institut Pertanian Bogor. Bogor. 259 pp.

Rozanah, A. 2004. Pencemaeran Teluk Jakarta. www_republika_co-id.htm. Tanggal 13 Juli 2006.

Utomo, A. D., S. Adjie, N. Muflikah, \& A. Wibowo. 2006. Distribusi jenis ikan dan kualitas perairan di Bengawan Solo. Jurnal Penelitian Perikanan Indonesia. Pusat Riset Perikanan Tangkap. Jakarta. 12 (2): 89-103.

Universitas Sebelas Maret. 2004. Limbah Cr (Cromium) dan Cd (Cadmium) di Karang Anyar, Solo sudah Masuk ke dalam Sistem Pertanian Padi. www. Liputan6.com. SCTV. Tanggal 15 Agustus 2004.

Universitas Muhamadiyah Surakarta. 2004. Ikan di Bengawan Solo sudah Tercermar Logam Berat. www. Liputan6.com. SCTV. Tanggal 15 Agustus 2004.

Universitas Diponegoro. 1992. Rencana Pengelolaan Lingkungan Waduk Wonogiri. Departemen Pekerjaan Umum. Pusat Penelitian Kependudukan dan Lingkungan Hidup. Universitas Diponegoro. Semarang. 
BAWAL: Vol.3 No.1-April 2010: 25-32

Lampiran 1. Persentase ammonia bebas terhadap ammonia total Appendix 1. Persentage of free ammonia to total ammonia

\begin{tabular}{ccccc}
\hline \multirow{2}{*}{$\mathrm{pH}$} & \multicolumn{5}{c}{ Suhu/Temperature $\left({ }^{\circ} \mathrm{C}\right)$} \\
\cline { 2 - 5 } & $\mathbf{2 6}$ & $\mathbf{2 8}$ & $\mathbf{3 0}$ & $\mathbf{3 2}$ \\
\hline 7,0 & 0,60 & 0,70 & 0,81 & 0,95 \\
7,2 & 0,95 & 1,10 & 1,27 & 1,50 \\
7,4 & 1,50 & 1,73 & 2,00 & 2,36 \\
7,6 & 2,35 & 2,72 & 3,13 & 3,69 \\
7,8 & 3,68 & 4,24 & 4,88 & 5,72 \\
8,0 & 5,71 & 6,55 & 7,52 & 8,77 \\
8,2 & 8,75 & 10,00 & 11,41 & 13,22 \\
8,4 & 13,20 & 14,98 & 16,96 & 19,46 \\
8,6 & 19,42 & 21,83 & 24,45 & 27,68 \\
8,8 & 27,64 & 30,68 & 33,90 & 37,76 \\
9,0 & 37,71 & 41,23 & 44,84 & 49,02 \\
9,2 & 48,96 & 52,65 & 56,30 & 60,38 \\
9,4 & 60,33 & 63,79 & 67,12 & 70,72 \\
9,6 & 70,67 & 73,63 & 76,39 & 79,29 \\
9,8 & 79,25 & 81,57 & 83,68 & 85,85 \\
10 & 85,82 & 87,52 & 89,05 & 90,58 \\
10,2 & 90,56 & 91,75 & 92,80 & 93,84 \\
\hline
\end{tabular}

Sumber/Sources: Boyd, 1988 dalam Effendie, 2000 